\title{
FROM CORPORATIONISM TO COOPERATIONISM: REVERSED GLOBALIZATION, COOPERATIVE POLITICS AND EXPANDING ONLINE COMMUNICATION IN POST-PANDEMIC TIME
}

\author{
RADOSŁAW FIEDLER ${ }^{1}$ \\ ${ }^{1}$ Adam Mickiewicz University in Poznań, Wieniawskiego 1, 61-712 Poznań, Poland. ORCID 0000-0003- \\ 1573-9898,Email: fiedler@amu.edu.pl
}

\begin{abstract}
In post-pandemic time a redefinition of politics and globalization is more than possible. There are a lot of possible scenarios - one of them is the cooperative model as an antidote to the polarized politics and corporative driven globalization. The aim of this short discussion paper is to present the proposal of the shift from corporationisim to cooperationism as a functional model in addressing challenges locally and globally.

KEYWORDS: globalization, politics, corporation, cooperation
\end{abstract}

The world in November 2019 was in a good economic condition, though several threats and problems could have easily disrupt or undermine the growth and caused instability. The annual growth of the global economy was almost 3\%. Growth in 2020 had been projected to 3.4 percent (International Monetary Fund 2019). Total international tourist arrivals reached 1,4 billion in 2019 with total international tourism exports (International tourism receipts plus passenger transport) altogether of an astronomic digit of USD 1.7 trillion (International Tourism Highlights 2019). Another example of a very intensive connectivity was the busiest air traffic on July 25,2019 , with more than 230 thousand flights cruise through the sky all around the globe. It was aviation's busiest day in history. The indicators given above are only a few chosen to exemplify 
interconnectivity and globalization in its apex.

In an ongoing discussion on globalization, the scholars and publicists have been analyzing this complicated process in its various aspects and nuances. For many of them, the globalization has created not only opportunities but disadvantages either.

The debate itself has provoked questions on the limits of globalization. About its scope, layers, technological and communicational attributes. The idea of globalization founded by the West was initially focused on trade with settling down tariffs and unconstrained flow of capital funds and investment. But in the following years, the globalization with its dynamism has included many other areas, such as intercommunication, internationalized labor. Globalization is a dynamic process and provokes the following questions: does interconnectivity mean that international cooperation has achieved a higher level of institutionalization and more advanced global governance? Does the global acceleration create functional international regimes dealing with a wide range of issues from security to technological, economic and financial cooperation? Although globalization has been a dynamic and multidimensional process, but it has not established the global government - apart from some examples of global governance as the World Trade Organization, World Bank, International Monetary Fund, European Union with its institutions and others highly professionalized in addressing strictly defined issues.

Globalization as a complicated process provoked the severe debates in the 1990s and 2000s, including often contradictory views and opinions. On the one hand, it was perceived as a new form of inequality and oppressiveness and even immoral corporative business (Beck 2000) to be found as an accelerator of democratization processes (Fukuyama 1992) or as the right recipe for a clash of civilization (Huntington 1997) on the other.

In the debates, the problem of deglobalization or reversed globalization has been omitted. Authors have praised various aspects and the intensity of globalization seemed to be an unstoppable process. The financial crisis from years 2008-2012 shaken the global finances and banks that were operating globally. The financial sector was deeply sunk in toxic credits and unable for self-regulation and badly needed state funds from taxpayers. Almost a billion USD of stimulus programs undertook by the United States did not reform substantially the financial sector and did not change the corporative drive of globalization. The conviction of unlimited growth has prevailed again without deep reflection. New potential bubbles have appeared on the horizon. Adam Tooze in his famous book about the negative ramifications of the financial crisis indicated that it brought to the sudden wave of populism in Europe and the United States. The most obvious examples among others were Brexit and the election of Donald Trump (Tooze 2019). After the financial crisis, a tendency to the reversed globalization and protectionism has been observed. The rise of populism has weakened the foundations of globalization and institutionalization and sharply defined its limits. Some societies have assumed a critical position to the concept of globalization at the expense of sovereignty.

Previously, the tendency for reemerging a more powerful state was initiated by terrorism - which gave a reliable excuse for curbing some of civil rights as accepted 
and necessary cost for security. Since 9/11 the state has reemerged more vital with a strengthened role in combating terrorism in all its forms, with additional capacity for surveillance. The United States spent enormous sums on the global war with terrorism (GWOT). As a result, the counter-terrorism has brought a deep instability in Afghanistan and Iraq. Almost twenty years have passed and Al Qaeda is operating and dispersing its cells to many other states through Asia, Africa, and the Middle East either. The other threats and challenges, such as nuclear proliferation, rising regional and global rivalry, proxy wars and growing influx of refugees to Europe were on the list before pandemic outbroke. As a result, the pandemic possible global spread seemed to be a far and no imminent threat. Except for some warning signals from the World Health Organization and signaled by Bill Gates the global pandemic in the $21^{\text {st }}$ century was a topic for the literature and the science-fiction movies (Gates 2018).

In late 2019 the SARS-CoV-2 outbroke in Wuhan. It seemed as other earlier pandemics to be curtailed much earlier without disrupting the economic activity within the states and globally. The novel virus has spread too rapidly and met with too slow counter-response. Probably decision-making procedures have been too slow even in autocratic China. Now is also difficult to assess how far are open and individualistic societies vulnerable to the spread of COVID-19? Is freedom put at risk?

For the first time in history, the global supply-demand chain has been so deeply disrupted and even partly paralyzed. Governments around the world have imposed lockdowns and other measures in a bid to slow the spread as the death toll caused by COVID-19 climbs to almost 40,000. Considering accounts of Imperial London College and gloomy predictions if left unchecked, COVID-19, the disease caused by the virus, could kill over half a million people in the United Kingdom and 2.2 million in the United States being a catastrophe for health-care system in both countries (Blyth 2020). After taking such drastic precautions the final death toll of a novel virus in the United States probably would be limited to 100.000 and according to the more pessimistic scenarios to 200.000 , or even - in the most pessimistic predictions - to dozens of hundreds of thousands.

Still, there is no final timeline for the full reopening of all economies deeply paralyzed by novel virus. For example, in New York City, the apex of the death toll is predicted in mid-April and is not certain how long the declining would take. It seems that many states will remain in a lock-down through all April and even May. Lockdowns lasting more than two months would cause an extremally deep economic recession and rampant, double-digit growth of unemployment. In February 2020 unemployment was the lowest since 1969. In early April 2020, the unemployment rate in the US has grown rapidly to 10 million already. It is very difficult to predict now how deep an economic recession would be. Since 1945, the Western economies have never been almost entirely locked-down.

Looking at the world after a pandemic can be treated as an intellectual exercise in forecasting different scenarios. It is highly hypothetic and probably inadequate because of the situation changing too rapidly. There are a lot of uncertainties because the pandemic is still going on and unresolved threat fastly spreading across many states and continents. It is not certain when the momentum of a post-pandemic time 
will be achieved and declared. A highly plausible scenario is existing for a long time in the midway between half-suppressed virus and necessity or reopening economies. In that model, the state apparatus is gaining almost unlimited possibility and excuse for surveillance of its citizens and curbing their freedoms with the application of the most modern technologies. The second problem is related to state capacity and resources in the fight against the novel coronavirus.

Lockdowns are causing damage to the economy and are negatively affecting the most sensitive branches such as tourism, events, restaurants, hotels, theaters and many others. The crisis entails both negative and positive effects for national and global economies. The crisis can be perceived as a reset and essential impulse for reorganizing the society and economy both on a local and global level.

Although it is much easier to depict the catastrophic scenario of the final economic collapse igniting conflicts and political turmoil, only positive ones will be taken into consideration in this text.

A basic assumption is that the crisis entails change and new openings with all resets, reforms, and corrections in order to avoid the next pandemic imbroglio or deep crisis from the rapidly going climate change. The current coronacrisis is perceived as a chance for a new remodeling of the economy, state, society, and international system.

As an urgent issue, the politics itself as the essence of organizing the political life and power on each of the levels from the bottom to the top should be reconsidered. Is it a possible change of political game? Is it a possible sustaining highly polarized political scene for example in Poland and the United States? The deeply polarized political scene will not be unable to deal with significant and devastating crisis and economic depression. Political rivalry is an asset of discourse in a democratic political system and a stable environment. Facing a deep crisis, the society is looking for leaders who can effectively deal with the recession. Moreover, political conflicts are provoking unnecessary tensions that can jeopardize the entire political system. Paraphrasing Donald Trump's slogan - making the community great again is essential needed to humble egoistic attitudes and particular interests. Solidarity and cooperative societal models seem to create a more supportive social environment. Innovation is essential for absorbing great numbers of unemployed people. Such a general idea was proposed by Bernie Sanders with his new green deal of promoting and implementing the energy without fossil fuels. Cooperative and subsidiary from the bottom to the top would impede positively for energizing democratic processes.

The cooperative model should be adapted in communities, states and globally. In the after the pandemic world, a cooperative approach can mitigate or slow-down threats including pandemics, climate crisis, refugees, cybersecurity and terrorism and other challenges. Wider perspective on these challenges would help to avoid wrong decisions and employing costly strategies.

The bitter lesson from the ongoing crisis is almost a lack of international solidarity in the fight against COVID-19. China due to Chinese New Year ignored the first outbreaks of a novel coronavirus and later has concealed some facts of it. Growing and annoying data should ignite drastic respond which was needed while the costs were not put at stake. The precious time was lost. An extreme example is the case of the 
United Kingdom where after initial reckless ignoring the novel virus, eventually, the authorities ordered strict quarantine, social distances and locked major places of the country. Inability and ineptness in responding to the COVID-19 both locally and internationally results in increasing spread of it and higher death toll and the cost for lock-down would reach skyrocketing trillions of US dollars. Another aspect is related to societal pain and insecurity caused by the recession. It is a chance for more effective, multilevel and international cooperation. The institutions like the World Health Organization and other forms of cooperation would be more effective and much better equipped to face new pandemic. Global threats need a global response. In the case of the COVID-19, it has been fragmented respond and the cost is a global recession. Knowledge sharing instead of lonely interpreted informations.

Another possible scenario would be a reversed globalization and more locally oriented production and supplies. The crisis is posing a challenge to several apparently unshaken aspects of globalization, such as interconnectivity, technological transfers with know-how and as creating a great opportunity for the development and investments in more inferior regions. The production is dispersed too much in different continents due to lower costs. Pandemic has shown the weakness of such assumptions e.g. the strategic US drugs and protective equipment have been being produced abroad. Globalized production is cheaper but riskier in case of an unexpected crisis as pandemic. Probable outcomes would be state regulations to reinforce the corporations to bring back its production to the home country. The most important economic benefits from globalization have been lost in the coronavirus locks-down. It would have a heavy impact on reversing this process.

With the reversed globalization, the international tourism would probably shrink around 50\% for some time due to both risks from the potential pandemic outbreaks and political instability in regions that are in the recession caused turmoil but also due to global pauperization. That tendency would be advantageous for local micro tourism.

A very crucial aspect of the global situation is a sudden increase of online communications - both in working and learning. Various technological solutions, especially apps such as Teams or Zoom are rapidly increasing its share in the cyber market. The online communication tools and techniques are advancing and are becoming more attractive, and whole societies are learning how to use it in everyday life. Apart from the educational sector, businesses - especially SMEs are going to be more active in online communication and management. After pandemic, the tendency may not reverse and it may become a necessity for educational and business to keep some aspects of their activities online.

\section{CONCLUSIONS}

We all are waiting for a great come back to public life with all our activities at work, schools, universities, business, entertainment or culture. Pandemic has envisaged us that our stable way of life is jeopardized. Prior COVID-19 the world was obsessed with the idea of economic growth driven by constantly growing consumption despite the 
red alerts of a global climate crisis approaching.

Pandemic is giving us all a generational experience, debunking the fragility of our stable existence. Now all our assumptions have been tested and there is the right moment for redefining and improving social, political and economic models the world is functioning within. It is just a small try how life in a global climate change crisis could function.

One of the improvements should be rethinking the idea of huge corporation driven false development, concentrating on the financial benefits at the expense of the natural environment, security and local communities' wellbeing. The ideological shift is more than needed, towards the concept more cooperationism and less corporationsim. The cooperative model should be adjusted to the political system and economy. The globalization was an advantageous process for great corporations. Their benefits have evaporated in time of corona-crisis which clearly exposed all global problems of too long and unsafe chains of production and supply. The next step would be decreasing oversees activity of many corporations and enforcing the comeback of some crucial business into the home market.

Finally, the politics should be redefined. The corona-crisis urges for a more coherent and responsible response to rising social tensions. The cooperative model of politics should be based on the broad consensus.

There are rare moments for undertaking a great reset - similar to this of year 1989 when communism collapsed. Tackling global threats seems to be possible only with a cooperative approach on different levels - from local communities to international relations. The COVID-19 has shaken our societies and economies. Probably this is the last such a mild global challenge before the next ones, probably harder and more destructive, climate change driven come around. The clock is ticking.

FUNDING: This paper is a result of visit at Columbia University in New York City within the Bekker Program the Polish National Agency for Academic Exchange.

CONFLICT OF INTEREST: The author declares no conflict of interest.

ACKNOWLEDGEMENTS: I would like to thank prof. Robert Jervis and Anna Schmidt-Fiedler.

\section{REFERENCES}

Beck, Ulrich. 2000. What is globalization? Cambridge, UK, Malden, MA: Polity Press. Blyth, Mark. 2020. “Why America’s Growth Model Suggests It Has Few Good Options.” Foreign Policy, March 30. Retrieved March 31, 2020 (https://www.foreignaffairs. com/articles/americas/2020-03-30/us-economy-uniquely-vulnerable-coronavirus?utm_campaign=tw_daily_soc\&utm_source=twitter_posts \&utm_medium=social ).

Fukuyama, Francis. 1992. The End of History and the Last Man. New York: Maxwell 
Macmillan International.

Gates, Bill. 2018. "Innovation for Pandemics." The New England Journal of Medicine 378:2057-2060. DOI: 10.1056/NEJMp1806283

International Tourism Highlights. 2019. Retrieved March 31, 2020 (https://www.e-unwto.org/doi/pdf/10.18111/9789284421152 ).

Huntington, Samuel P. 1997. The Clash of Civilizations and the Remaking of World Order. New York: Touchstone.

Tooze, Adam. 2019. Crashed: how a decade of financial crises changed the world. London: Penguin Books.

World Economic outlook International Monetary Fund Global Manufacturing Downturn, Rising Trade Barriers. 2019. Retrieved March 30, 2020 (https://www.imf. org/en/Publications/WEO/Issues/2019/10/01/world-economic-outlook-october-2019).

\section{BIOGRAPHICAL NOTE}

Radoslaw Fiedler is an associate professor at Adam Mickiewicz University in Poznan, Poland. He is also a deputy dean for international cooperation and head of the Department for Non-European Political Studies at the Faculty of Political Science and Journalism. Chairman of the Fiedler's Foundation. In the academic year 2019-2020 prof. Fiedler is a visiting scholar (the Bekker Program - the Polish National Agency for Academic Exchange) at the Arnold A. Saltzman Institute of War and Peace Studies.

OPEN ACCESS: This article is distributed under the terms of the Creative Commons Attribution Non-commercial License (CC BY-NC 4.0) which permits any non-commercial use, and reproduction in any medium, provided the original author(s) and source are credited.

ARTICLE HISTORY: Received 2020-03-31 / Accepted 2020-04-10 
